\title{
C15 アオダイショウ幼蛇咬傷の2例とマムシ咬傷の2例
}

○塩田恒三 ${ }^{1}$, 竹中秀也 ${ }^{2}$, 後藤智子 ${ }^{2}$, 村上正文 ${ }^{2}$, 宮本はるみ ${ }^{2}$, 片上千絵 $^{2}$, 齋藤卓也 ${ }^{2}\left({ }^{1}\right.$ 京都府大・医動 物, 京都府大・皮膚)

Two cases of juvenile blue-green snake (Elaphe climacophora) bites and 2 cases of mamushi (Agkistrodon halys) bites

Shiota, T., Takenaka, H., Goto, T., Murakami, M., Miyamoto, H., Katakami, C., Saito, T.

(1)8歳，男性．右第4指を咬まれ1時間後へビを持って受診。咬み口は1個, 軽度疼痛，発赤，腫髟は認めず，咬み 口を洗浄. ソリ夕Tの投与等で経過観察. ヘビは体調 $33 \mathrm{~cm}$ のアオダイショウの幼蛇. (2)40歳，男性. キャンプ中に 左下腿を咬まれ蛇を持って受診. 3 条の線状の紅班を認め, 出血傾向は認めず，経過観察．へビは体長約 $35 \mathrm{~cm}$ のア オダイショウの幼蛇で，上䫑に4列の，長さ約 $1 \mathrm{~mm}$ の鈎が各20本程度縱に並び，一部は脱落．(3)20藏，男性. 咬傷 4

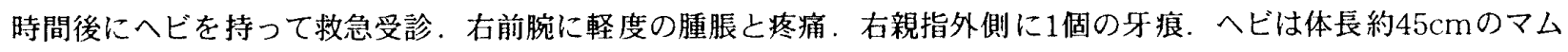
シの成蛇. セファランチンを中心とした治療を 2 日間行い, 疼痛, 腫脹は軽減. (4) 9 藏, 男性. 下校時に左第2指を咬 まれ，咬傷35分後にへビを持って救急受診.へビは体長約 $22 \mathrm{~cm}$ のマムシの幼蛇. 牙痕 1 個を認め手関節部まで腫脹,

疼痛. マムシ抗毒素ウマ血清とセファランチン等を併用. 5時間後左手全体腫脹. 第3病日には腫脤も軽減. アオダ イショウ幼蛇の背面の斑紋がマムシのそれと一見して似ていることから注意が必要と考えられた.

\section{C16 血圧低下を伴ったツツガムシ病の 1 例}

O大滝倫子 ${ }^{1}$, 古屋由美子 ${ }^{2}$ ( ${ }^{1}$ 九段坂病院, ${ }^{2}$ 神奈川衛研)

A case report of Tsutsugamushi disease with hypotension

Ohtaki, N., Furuya, Y.

症例：59歳，女性. 初診: 平成 13 年 11 月 28 日. 現病歴：同年 11 月 10 日より 11 日にかけ山中湖付近を 旅行中, 富士山簏演習地近くで落ち葉を集めた。 11 月 20 日より $39-40^{\circ} \mathrm{C} の$ 発熱と右腋に痛みを覚え， 11 月 23 日近医を受診, 感冒薬, 解熱梸を処方. 翌日( 11 月 24 日)より皮疹を生じ, 薬将を疑われて服薬は中止. 発熱, 皮疹は軽快せず。1 1 月 28 日（第 9 病日）当科受診, 即刻入院の上ミノサイクリンの治療を開始したが，30日ま での 3 日問 $38-9^{\circ} \mathrm{C}$ 発熱が続いた．初疹時には顔面を含む全身に紅斑が散発し，右腋窩に刺し口，それに接して リンパ節の腫脹を認めた．検查結果：血小板 9.7 万，血圧 78/40。抗体価：Kuroki 株に対し，急性期 IgM: 160, IgG: <10, 快復期 IgM: 1280, IgG: 320 などの価を示した. 